\title{
It is a real hazelnit allergy? The CCD interference
}

\author{
Antonio Nicola Romeo, Giuseppe Menna* \\ From Food Allergy and Anaphylaxis Meeting 2011 \\ Venice, Italy. 17-19 February 2011
}

\section{Bacground}

Cross-reactive carbohydrate determinants $(\mathrm{CCD})$ are carbohydrates chains in glycoproteins. Capable of binding human IgE from allergic they could play a role in the cross-reactivity between allergens from unrelated sources; their function still a matter of debate.

\section{Objective}

Pollen is the most important cause of the production of IgE anti-CCD. Which have been described in trees and herbs. We investigated the relationship between clinical anaphylaxis to hazelnut and the sierological positivity to nuts allergen, grasses and role of interference by antiCCD IgE.

allergies to foods, latex or venom, especially in pollinosis This can lead to unnecessary therapy.

Published: 12 August 2011

\section{Reference}

1. lacovacci $P$, Pini $C$, Afferni $C$, Barletta $B$, Tinghino $R$, Schininà $E$, Federico $R$, Mari A, Di Felice G: A monoclonal antibody specific for a carbohydrate epitope recognizes an IgE-binding determinant shared by taxonomically unrelated allergenic pollens. In Clin Exp Allergy. Volume 31. Department of Immunology, Istituto Superiore di Sanità, V. la Regina Elena, 299, 1-00161 Rome, Italy; 2001:(3):458-65.

doi:10.1186/2045-7022-1-S1-P71

Cite this article as: Romeo and Menna: It is a real hazelnit allergy? The CCD interference. Clinical and Translational Allergy 2011 1(Suppl 1):P71.

\section{Methods}

A six year old twins, atopic risk, father suffering from pollen asthma, reported by parents adverse reaction (Sampson, 2003 1st -2 nd grade) to hazelnut at first assumption.

\section{Results}

Skin tests positive for nuts and grasses, no mite high RAST positivity for grasses, over $100 \mathrm{KUI} / \mathrm{L}$, Alternaria $34 \mathrm{KUI} / \mathrm{L}$, Phl-1 83,1KUI/L, Alt a-1- 43KUI/L, Cor a8 negative, Nuts negative, MUFXF3 ( CCD) $2.83 \mathrm{U} / \mathrm{ml}$. Food Challenge after 1 year: negative, Now allergic rhinithis.

\section{Conclusion}

IgE anti-CCD should not be able to connect mast cells and basophils and release inflammatory mediators. Patients with IgE restricted to CCD have not clinical symptoms. CCD can be considered as a potential interference in atopic diagnosis; especially in polisensitized. It 's important to provide clinical information to laboratory test. IgE -anti CCD create a misdiagnosis of

Submit your next manuscript to BioMed Central and take full advantage of:

- Convenient online submission

- Thorough peer review

- No space constraints or color figure charges

- Immediate publication on acceptance

- Inclusion in PubMed, CAS, Scopus and Google Scholar

- Research which is freely available for redistribution 